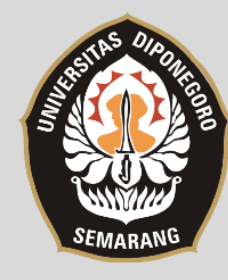

pISSN : $1829-8370$ eISSN : 2301-9069

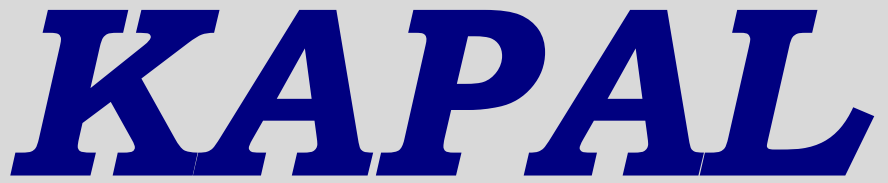

JURNAL ILMU PENGETAHUAN \& TEKNOLOGI KELAUTAN

\title{
Rancang Bangun Kapal Klasik Untuk Ekowisata di Perairan Terbatas
}

Sunardi $^{1)}$, Sukandar ${ }^{1)}$, Eko Sulkhani $^{\text {I) }}$, Abu Bakar Sambah ${ }^{\left.1{ }^{*}\right)}$, Agus Tumulyadi ${ }^{1)}$

${ }^{1)}$ Fakultas Perikanan dan Ilmu Kelautan, Universitas Brawijaya, Jalan Veteran Malang 65145

\begin{abstract}
Abstrak
Perkembangan ekowisata bahari mengalami kemajuan yang pesat selama beberapa tahun terakhir dan memberikan manfaat besar untuk masyarakat pesisir dan nelayan. Kebutuhan sarana transportasi berupa kapal wisata untuk menunjang kegiatan wisata bahari masih sangat besar dan sangat berpotensi untuk ditingkatkan. Kapal wisata untuk kebutuhan wisata yang ada saat ini adalah kapal nelayan yang masih terkesan kurang menarik dan tidak dilengkapi dengan sarana keselamatan maupun akomodasi yang memadai. Penelitian ini mencoba untuk mengembangkan desain kapal kayu klasik yang sesuai untuk wisata di perairan terbatas dengan penumpang sampai dengan 5 orang. Penelitian ini menerapkan pendekatan perbandingan dengan kapal pembanding sebagai pengujian desainnya, serta menerapkan parametric design, yaitu suatu metode yang digunakan untuk mengotimalkan desain suatu kapal dengan mempertimbangkan seтиа variabel, seperti ukuran kapal, kecepatan kapal, kemampuan mesin dan power mesin yang dibutuhkan untuk menggerakkan kapal. Batasan desain yang digunakan adalah kapal harus dapat diproduksi oleh galangan kapal tradisional dengan biaya produksi yang murah. Hasil penelitian ini menghasilkan desain kapal serta fisik kapal klasik secara utuh dengan material kayu dan mampu melaju dengan kecepatan 5 knot dengan menggunakan mesin 4HP (Horse Power). Hasil desain dan uji coba berlayar terhadap kapal yang dibuat menunjukkan stabilitas yang sangat bagus untuk beroperasi di perairan bebas.
\end{abstract}

Copyright @ 2018, KAPAL, pISSN:1829-8370, eISSN : 2301-9069

Kata Kunci : Rancang bangun, kapal klasik, ekowisata

\section{PENDAHULAN}

Ekowisata bahari yang berkembang pesat di Indonesia memberikan dampak yang besar pada kesejahteraan di masyarakat [1]. Di beberapa tempat wisata, sebagian nelayan menyewakan kapal ikannya sebagai kapal wisata, seperti yang teradi pada nelayan Karimunjawa dikarenakan hasil tangkapan yang semakin menurun [2][3]. Sarana utama wisata bahari yang utama adalah kapal wisata, namun yang ada di hampir semua kawasan wisata di Indonesia adalah menggunakan

*) Penulis Korespondensi :

Email : absambah@ub.ac.id kapal ikan sekaligus sebagai kapal wisata. Gambar dibawah ini menunjukkan kapal-kapal ikan yang digunakan sebagai kapal wisata [4].

Permasalahan yang ada dari penggunaan kapal ikan sebagai kapal wisata adalah; (1) Kapal dibuat tidak berdasarkan aturan keselamatan standard. Kapal ikan yang dibuat di seluruh Indonesia hampir seluruhnya dibuat berdasarkan kultur turun temurun dari pengalaman yang diwarisi oleh pendahulu-pendahulunya. Aturan keselamatan terkait dengan stabilitas kapal, sekat kapal yang harus ada untuk mencegah kapal teggelam ketika bocor tidak diperhartikan dalam desain kapalnya; (2) Kapal tidak memiliki alat keselamatan standard. Beberapa kapal ikan yang dijadikan kapal wisata tidak dilengkapi dengan 
peralatan komunikasi, penanda isyarat bahaya dan sejenisnya, yang mana hal tersebut adalah peralatan standard kapal ketika kapal menghadapi bahaya. Alat keselamatn yang disediakan adalah life jacket dan jumlahnya kadang terbatas, tidak semua penumpang mendapatkannya. Alat keselamatan standard sangat diperlukan untuk menjamin keselamatan kapal penumpang [5]; (3) Kapal kurang memperhatikan kenyamanan penumpang. Kesan kurang terawat dan tidak tersedianya tempat duduk, ruang penyimpanan makanan yang nyaman untuk kapal wisata sering dijumpai di beberapa lokasi wisata. Penyedia jasa kapal wisata hanya berorientasi pada memaksimalkan jumlah wisatawan yang naik di atas kapal. Sangat penting untuk memperhatikan kenyamanan penumpang sehingga menimbulkan image positif tempat wisata pada pengunjung [6]; (4) Desain kapal kurang menarik untuk keperluan wisata. Kapal ikan yang dijadikan sebagai kapal wisata dari segi desain secara umum kurang menarik, menilik pada kebutuhan jaman sekarang untuk ber swa-foto dan dipasang di media sosial, kapal yang menarik akan bisa meningkatkan antusias wisatawan untuk melakukan wisata bahari.

Berdararkan permasalahan dan urgensi penelitian sebagaimana disampaikan diatas, maka kegiatan penelitian terkait rancang bangun kapal klasik untuk keperluan ekowisata khusus untuk daerah perairan terbatas ini penting untuk dilakukan. Selain menghasilkan desain kapal klasik sesuai standar yang telah ditetapkan, hasil desain ini juga diaplikasikan dalam pembuatan kapan secara nyata, sehingga kegiatan percobaan berlayar dapat dilakukan untuk melihan ketahanan hasil desain.

\section{METODE}

Penelitian ini menerapkan pendekatan perbandingan dengan kapal klasik yang telah ada guna menguji desain dan kestabilannya, serta menerapkan metode parametric design.

1. Kapal pembanding

Pada pendekatan ini, kapal yang telah terbukti memiiki performance yang bagus dijadikan sebagaia acuan desain kapal, sehingga proses desain kapal tidak terlalu lama. Kapal pembanding yang diambil adalah kapal yang diproduksi oleh Christ Craft, salah satu perusahaan kapal kecil di USA (Gambar 1) dan kapal pembanding kedua yang diambil dari 268 Austin Vintage and Antique Boat (Gambar 2)

\section{Parametric Design}

Dalam proses pembangunan kapal tentu perancang/pembangun kapal memiliki tujuantujuan tertentu sehingga desain yang dibuat memiliki keuntungan yang maksimal seperti membuat desain dengan ukuran utama yang paling minimal dengan batasan requirement yang diberikan, meminimalkan daya mesin yang dibutuhkan, meminimalkan biaya material, dan meminimalkan biaya pembangunan [7]. Ditinjau dari sisi pemilik kapal tentu mereka menginginkan biaya kapital yang kecil, biaya operasional yang kecil, namun memiliki efisiensi operasional yang maksimal. Untuk mencapai hal tersebut hal yang biasa dilakukan adalah dengan melakukan studi parametrik. Tujuan yang mendasar dari studi parametrik adalah untuk mendapatkan ukuran dan koefisien kapal yang paling menguntungkan dengan mengkombinasikan ukuran dan koefisien tersebut. Salah satu contoh studi parameter adalah dengan mengkombinasikan antara displacement, koefisien prismatik, rasio lebar dan sarat kapal, rasio kecepatan dan panjang kapal, serta koefisien midship sehingga didapatkan kombinasi yang dianggap

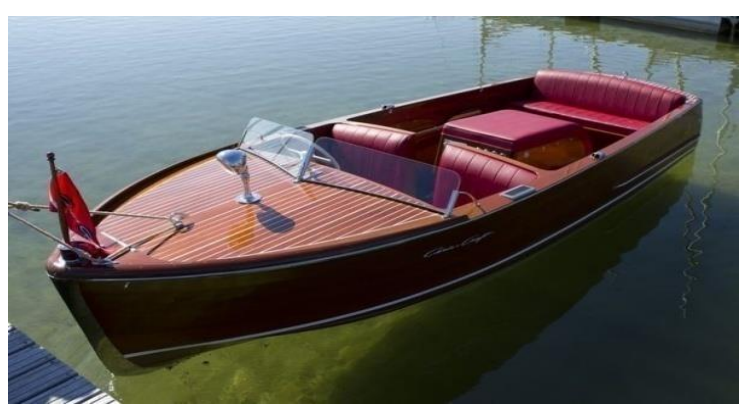

paling menguntungkan.

Gambar 1. Kapal pembanding 1

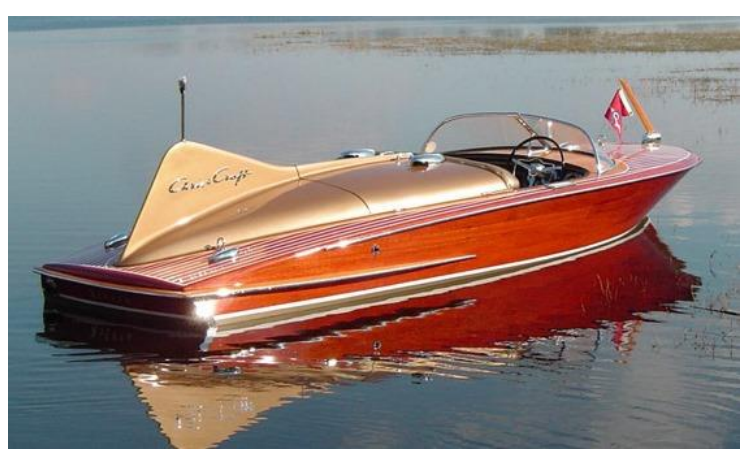

Gambar 2. Kapal pembanding 2

\section{HASIL DAN PEMBAHASAN}

Perencanaan rancang bangun kapal klasik dalam penelitian ini dilakukan dengan didasarkan pada asumsi dan parameter desain kapal yang 
secara nyara akan dibangun dan diujicobakan diperairan. Parameter yang digunakan dalam perancangan dan pembangunan kapal klasik untuk tujuan ekowisata dalam penelitian ini sebagaimana dijelaskanberikut.

\subsection{Keperluan dan Komponen Kapal}

Keperluan desain kapal wisata klasik ini adalah untuk 5 penumpang dengan kecepatan kapal antara 5-10 knot. Kapal juga di rancang untuk dapat beroperasi di laut lepas dengan tinggi gelombang kurang dari 1 meter. Sedangkan komponen berat kapal terdiri dari berat kapal kosong sebesar 0,25 ton, berat sistem permesinan sebesar 0,1 ton, dan jumlah 5 penumpang (@80 $\mathrm{Kg}$ ) sebesar 0,4 ton. Dengan demikian total berat kapal dan isinya adalah 0,75 ton.

\subsection{Rencana Garis (Lines Plan)}

Rencana garis merupakan gambar bentuk lambung kapal yang berupa garis perpotongan gading, garis air dan penampang memanjang kapal yang nantinya akan dijadikan dasar dalam pembagian ruangan-ruangan di kapal, bentuk gading, konstruksi memanjang kapal, kulit kapal dan sebagainya. Gambar rencana garis dilakukan dengan aplikasi desain kapal dengan dibantu aplikasi komputer. Rencana garis yang telah di desain sebagaimana pada Gambar 3, Gambar 4, dan Gambar 5.

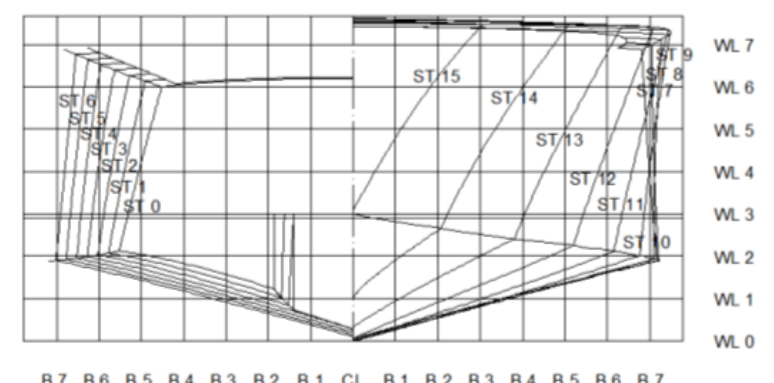

Gambar 3. Rancang garis kapal tampak depan

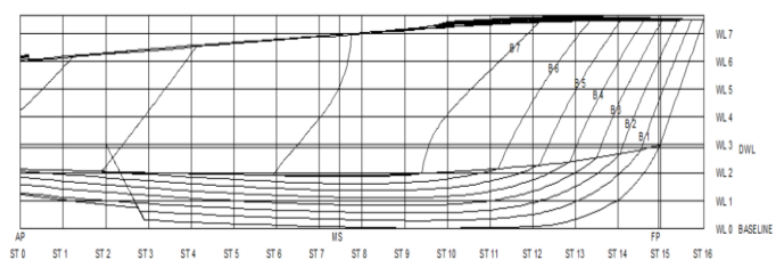

Gambar 4. Rancang garis penampang memanjang kapal

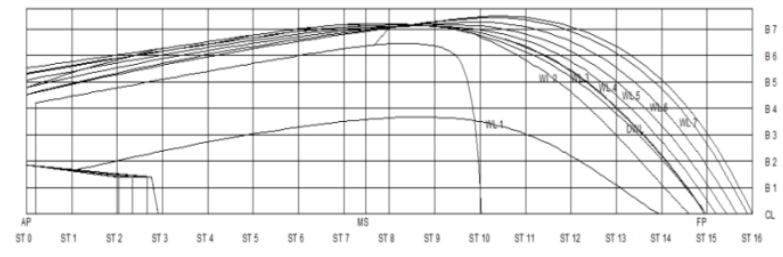

Gambar 5. Rancang garis penampang garis air kapal

Gambar rencana garis sebagaimana telah digambarkan diatas telah mengalami banyak penyesuaian dengan mempertimbangkan letak mesin dan dimensi mesin, jumlah penumpang, layout diatas geladak kapal, perhitungan tahanan kapal dan stabilitas kapal dalam berbagai skenario kondisi.

\subsection{Hidrostatis}

Perhitungan hidrostatis kapal diperlukan untuk mendapatkan berbagai karakteristik kapal untuk berbagai kedalaman kapal yang berbeda. Perhitungan berbagai ukuran dan koefisien kapal diukur mulai dari sarat kapal 0 meter sampai dengan sarat kapal 3 meter. Kurva hidrostatis dalam rancang bangun kapal klasik pada penelitian ini sebagaimana dijelaskan pada Tabel 1 dan Gambar 6.

Tabel 1. Kurva Hidrostatis

\begin{tabular}{|c|c|c|c|c|}
\hline Sarat Kapal (meter) & $\mathbf{0}$ & 1 & 2 & 3 \\
\hline Displacement (ton) & 0 & 0.0733 & 0.3589 & 0.7809 \\
\hline Heel (degree) & 0 & 0 & 0 & 0 \\
\hline Draft at $F P(m)$ & 0 & 0.1 & 0.2 & 0.3 \\
\hline Draft at $A P(m)$ & 0 & 0.1 & 0.2 & 0.3 \\
\hline Draft at $L C F(m)$ & 0 & 0.1 & 0.2 & 0.3 \\
\hline Trim $(+v e$ by stern) $(m)$ & 0 & 0 & 0 & 0 \\
\hline $\begin{array}{l}\text { WL Length }(m) \\
\text { Beam max extents on }\end{array}$ & 0 & 3.221 & 3.652 & 3.744 \\
\hline$W L(m)$ & 0 & 0.734 & 1.442 & 1.43 \\
\hline Wetted Area $\left(m^{\wedge} 2\right)$ & 0 & 1.699 & 4.311 & 5.359 \\
\hline Waterpl. Area $\left(m^{\wedge} 2\right)$ & 0 & 1.61 & 3.944 & 4.17 \\
\hline Prismatic coeff. $(C p)$ & 0 & 0.607 & 0.651 & 0.7 \\
\hline $\begin{array}{l}\text { Block coeff. }(\mathrm{Cb}) \\
\text { Max Sect. area coeff. }\end{array}$ & 0 & 0.302 & 0.333 & 0.474 \\
\hline $\begin{array}{l}(\mathrm{Cm}) \\
\text { Waterpl. area coeff. } \\
\text { (Cwp) } \\
\text { LCB from zero pt. (+ve }\end{array}$ & 0 & 0.502 & 0.749 & 0.682 \\
\hline $\begin{array}{l}f w d)(m) \\
L C F \text { from zero pt. }(+v e\end{array}$ & 1.75 & 1.997 & 1.838 & 1.793 \\
\hline$f w d)(m)$ & 1.75 & 1.933 & 1.728 & 1.781 \\
\hline$K B(m)$ & 0.996 & 0.069 & 0.139 & 0.199 \\
\hline$K G(m)$ & 0.25 & 0.25 & 0.25 & 0.25 \\
\hline
\end{tabular}




\begin{tabular}{lrrrr}
\hline \multicolumn{1}{c}{ Sarat Kapal (meter) } & \multicolumn{1}{c}{$\mathbf{0}$} & \multicolumn{1}{c}{$\mathbf{2}$} & \multicolumn{1}{c}{$\mathbf{2}$} \\
\hline$B M t(m)$ & 0 & 0.757 & 1.573 & 0.759 \\
$B M L(m)$ & 0 & 11.457 & 8.666 & 4.681 \\
$G M t(m)$ & 0.746 & 0.577 & 1.462 & 0.708 \\
$G M L(m)$ & 0.746 & 11.276 & 8.556 & 4.63 \\
$K M t(m)$ & 0.996 & 0.827 & 1.712 & 0.958 \\
$K M L(m)$ & 0.996 & 11.526 & 8.806 & 4.88 \\
Immersion $(T P c)$ & 0 & 0.017 & 0.04 & 0.043 \\
tonne/cm & 0 & 0.002 & 0.008 & 0.01 \\
MTc tonne. $(m)$ & & & &
\end{tabular}

Beberapa informasi penting yang didapat dari Tabel 1 diatas adalah kapal akan memiliki sarat $0,3 \mathrm{~m}$ dengan berat kapal seisinya 0,781 ton. Untuk berat kapal beserta isinya sebesar 0,75 ton, maka sarat kapal adalah 0,27 meter. Nilai sarat kapal ini sangat menetukan untuk perhitungan tahanan dan stabilitas kapal.

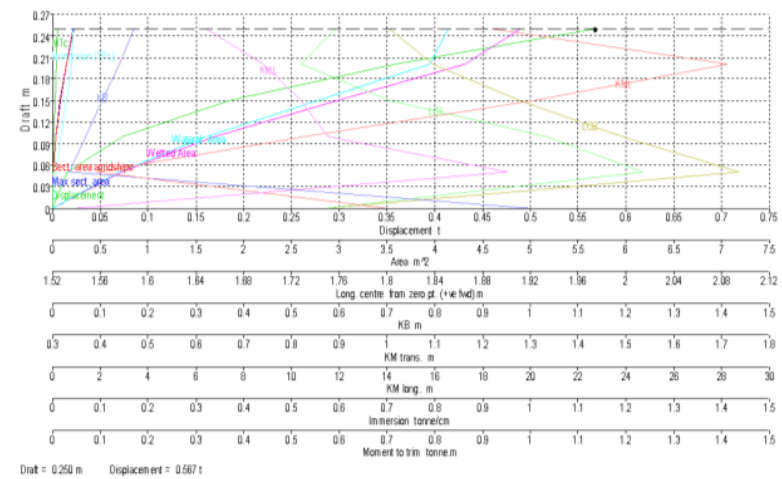

Gambar 6. Kurva hidrostatis kapal

\subsection{Rancangan Kapal}

Rancangan kapal di atas dek disusun sedemikian rupa sehingga penumpang dapat melakukan aktifitas di atas dek dengan tanpa berbagai hambatan. Posisi kursi dan kemudi ditempatkan agar pengemudi dapa mengemudikan kapal dengan duduk dan nyaman. Penempatan distribusi muatan juga mempertimbangkan stabilitas kapal. Rancangan kapal dalam berbagai sudut desai disampaikan pada Gambar 7, Gambar 8, Gambar 9, dan Gambar 10.

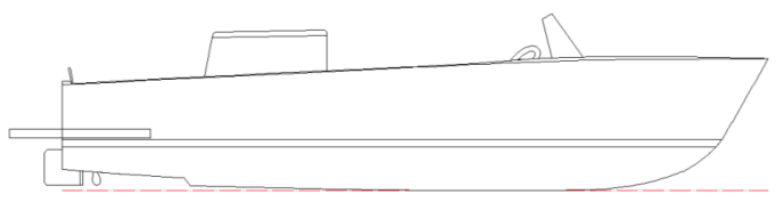

Gambar 7. Motorboat tampak samping

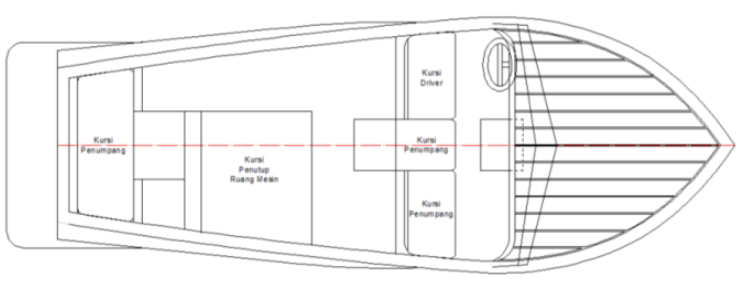

Gambar 8. Motorboat di atas dek

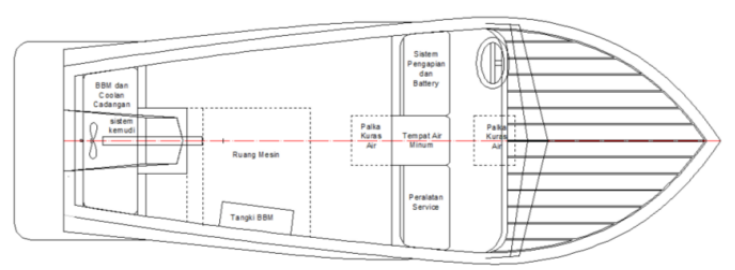

Gambar 9. Motorboat di bawah dek

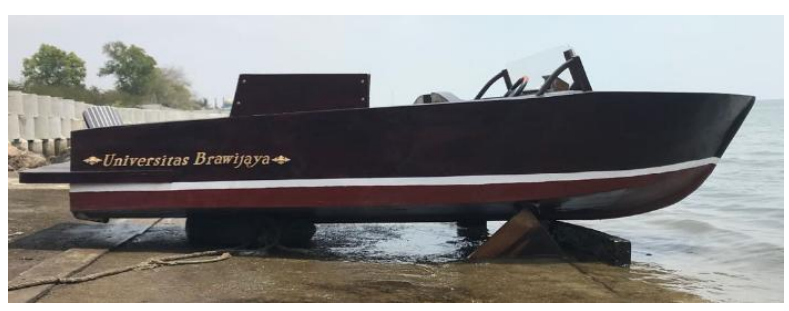

Gambar 10. Kapal hasil perancangan setelah proses finishing

\subsection{Perhitungan Prediksi Tahanan Kapal}

Perhitungan tahanan yang dilakukan adalah menggunakan metode Holtrop yang sesuai untuk kapal kecil dan kapal ikan [8], dimana perhitungan nya dibantu aplikasi komputer. Hubungan antara kecepatan kapal dengan tahanan dan daya kapal sebagaimana pada Tabel 2, sedangkan grafik hubungan tahanan dan kecepatan kapal sebagaimana digambarkan pada Gambar 11.

Tabel 2. Hubungan kecepatan dengan tahanan dan daya kapal

\begin{tabular}{ccc}
\hline $\begin{array}{c}\text { Kecepatan } \\
(\text { Knot })\end{array}$ & $\begin{array}{c}\text { Tahanan } \\
(\mathbf{k N})\end{array}$ & $\begin{array}{c}\text { Daya } \\
(\mathbf{H P})\end{array}$ \\
\hline 0 & -- & -- \\
1 & 0 & 0,008 \\
2 & 0 & 0,058 \\
3 & 0 & 0,188 \\
4 & 0,1 & 0,543 \\
5 & 0,2 & 1,46 \\
6 & 0,4 & 3,705 \\
7 & 0,7 & 6,391 \\
8 & 0,8 & 8,436 \\
9 & 0,8 & 10,395 \\
10 & 0,9 & 12,65 \\
\hline
\end{tabular}




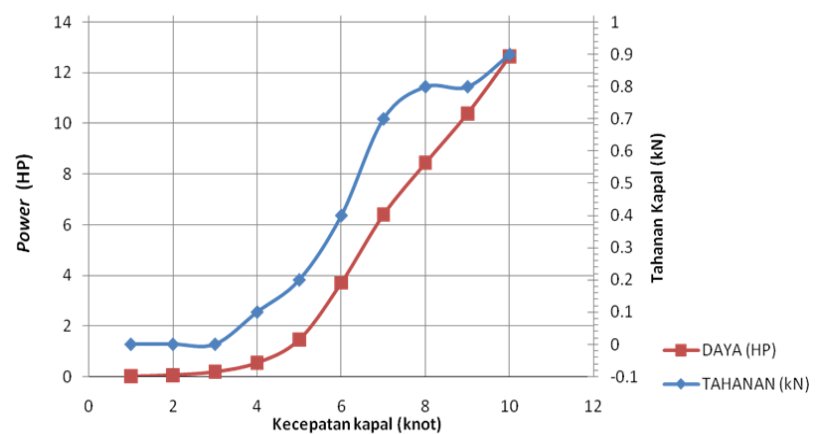

Gambar 11. Grafik hubungan tahanan dan kecepatan kapal

Perhitungan tahanan dan kekuatan kapal diatas mengunakan asumsi; (a) efisiensi propeller adalah sebesar 50\%, dan (b) pendekatan kapal di uji cobakan di perairan yang sangat tenang dan tidak ada arus atau gelombang tinggi yang mengganggu.

\subsection{Pemilihan Mesin}

Pemilihan mesin mengacu pada kecepatan kapal diinginkan. Sebagai contoh untuk mencapai kecepatan kapal 5 knot, maka tahanan kapal adalah 1,46 HP. Pemelihan mesin ini mempertimbangkan:

1. Sea Margin, sebagai koreksi karena kapal nanti akan di operasikan di perairan bebas, maka tahanan kapal ditambah 15\% dari total tahanan kapal

2. Gear box, karena pengaruh gesekan pada sistem permesinan, maka tidak semua energi putaran mesin diteruskan ke propeller, Tambahan koreksi 15 persen digunakan sebagai pertimbangan pengaruh ini.

3. $85 \%$ Maximum Continuous Rating, mesin kapal tidak dapat dipaksakan untuk bekerja dengan kecepatan maksimum secara terus menerus. Secara efektif, kecepatan mesin ratarata dioperasikan dengan kecepatan $85 \%$ dari beban mesin.

Contoh perhitungan pemilihan mesin kapal dengan mempertimbangkan kehilangan daya karena ketiga faktor diatas adalah sebagai berikut:

- Pengaruh sea margin = 1,46 HP x $1,15 \%$

$=1.67 \mathrm{HP}$

- Pengaruh gear box $=1,67$ HP x 1,15

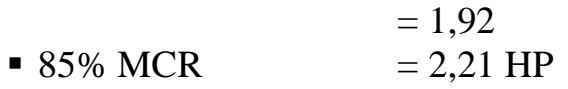

Dengan demikian untuk mencapai kecepatan 5 knot, diperlukan mesin dengan daya sekitar 3 HP. Secara lengkap kebutuhan daya mesin penggerak kapal untuk berbagai kecepatan kapal adalah sebagaimana dijelaskan pada Tabel 3 .

Tabel 3. Hubungan antara kecepatan kapal dan daya motor penggerak

\begin{tabular}{cccccc}
\hline $\begin{array}{c}\text { Kecepatan } \\
\text { (Knot) }\end{array}$ & $\begin{array}{c}\text { Tahanan } \\
(\mathrm{kN})\end{array}$ & $\begin{array}{c}\text { Daya } \\
(\mathrm{Hp})\end{array}$ & $\begin{array}{c}+15 \% \\
(\mathrm{Sea} \\
\text { Margin })\end{array}$ & $\begin{array}{c}+15 \% \\
(\mathrm{Gear} \\
\text { Box })\end{array}$ & $\begin{array}{c}+15 \% \\
(85 \% . \\
\text { Mcr }\end{array}$ \\
\hline 1 & 0 & 0,008 & 0,0 & 0,0 & 0,01 \\
2 & 0 & 0,058 & 0,1 & 0,1 & 0,09 \\
3 & 0 & 0,188 & 0,2 & 0,2 & 0,29 \\
4 & 0,1 & 0,543 & 0,6 & 0,7 & 0,83 \\
5 & 0,2 & 1,46 & 1,7 & 1,9 & 2,22 \\
6 & 0,4 & 3,705 & 4,3 & 4,9 & 5,63 \\
7 & 0,7 & 6,391 & 7,3 & 8,5 & 9,72 \\
8 & 0,8 & 8,436 & 9,7 & 11,2 & 12,83 \\
9 & 0,8 & 10,395 & 12,0 & 13,7 & 15,81 \\
10 & 0,9 & 12,65 & 14,5 & 16,7 & 19,24 \\
\hline
\end{tabular}

Berdasarkan Tabel 3, untuk mendapatkan kecepatan kapal 10 knot, setidaknya diperlukan mesin dengan daya 19,24 HP, sementara yang ada di pasaran adalah mesin dengan daya $20 \mathrm{HP}$, maka mesin ini yang dapat dipilih. Menghasilkan kecepatan lebih tinggi daripada yang diinginkan oleh pemesan akan lebih baik jika dibandingkan dengan kecepatan kapal lebih rendah dari yang diinginkan konsumen.

\subsection{Stabilitas Kapal}

Perhitungan stabilitas kapal dilakukan untuk mengetahui kemampuan kapal kembali ke posisi semula ketika mendapat gaya dari luar (gelombang, angin dan sebagainya). Perhitungan stabilitas untuk kapal ini dilakukan dengan 4 kondisi pemuatan (load case) yang berbeda. Hal ini disebabkan karena untuk setiap kondisi pemuatan akan memberikan nilai parameter stabilitas yang berbeda-beda; (1) Load Case 1 dengan 1 penumpang; (2) Load Case 2 dengan 2 penumpang; (3) Load Case 3 dengan 3 penumpang; dan (4) Load Case 4 dengan 4 penumpang.

Load case yang paling tidak stabil adalah ketika kondisi kapal dengan muatan paling sedikit, dimana pada saat itu sarat kapal tinggi dan kapal rawan untuk terbalik. Stabilitas kapal dengan satu penumpang adalah sebagai berikut:

\section{a. Distribusi Pembebanan}

Distribusi muatan pada kondisi pemuatan 1 adalah sebagaimana pada Tabel 4 dan Gambar 12. 
Tabel 4. Distribusi muatan load case 1

\begin{tabular}{lcccl}
\hline \multirow{2}{*}{ Beban } & \multirow{2}{*}{$\begin{array}{c}\text { Berat } \\
\text { (ton) }\end{array}$} & $\begin{array}{c}\text { Memanjang } \\
\text { (dari AP) }\end{array}$ & $\begin{array}{c}\text { Meninggi } \\
\text { (A.B.L.) }\end{array}$ & $\begin{array}{l}\text { Melintang } \\
\text { (From CL) }\end{array}$ \\
\cline { 3 - 5 } $\begin{array}{l}\text { Berat kapal } \\
\text { kosong }\end{array}$ & 0,300 & 1,750 & 0,000 & 0,000 \\
\hline BBM Utama & 0,009 & 1,100 & 0,500 & $-0,175$ \\
\hline $\begin{array}{l}\text { BBM } \\
\text { Cadangan } \\
\text { Kanan }\end{array}$ & 0,007 & 0,260 & 0,305 & 0,340 \\
\hline $\begin{array}{l}\text { BBM } \\
\text { Cadangan }\end{array}$ & 0,007 & 0,260 & 0,305 & $-0,340$ \\
Kiri & & & & \\
\hline Mesin & 0,075 & 0,900 & 0,300 & 0,175 \\
\hline Radiator & 0,005 & 1,200 & 0,400 & 0,000 \\
\hline Baterai & 0,005 & 1,900 & 0,250 & 0,400 \\
\hline Pengemudi & 0,0700 & 1,900 & 0,500 & $-0,400$ \\
\hline Berat Total & 0,409 & LCG $=1,577$ & VCG $=0,146$ & TCG $=-0.030$ \\
\hline & & & & \\
\hline
\end{tabular}

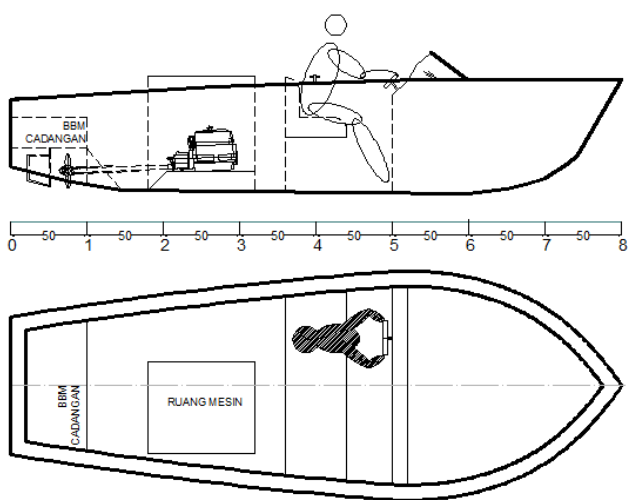

Gambar 12. Distribusi berat Load case 1

\section{b. Kondisi Kesetimbangan kapal (Equilibrium)}

Pada bagian ini akan tampak bagaimana kapal pada kondisi setimbang, sarat kapal bagian belakang $($ draft $\mathrm{AP})=0,287$ meter lebih tinggi dari pada ketinggian sarat bagian depan (draft at $\mathrm{FP})=0,161$ meter, sehingga secara memanjang kapal mengalami trim buritan dan ini baik untuk kecepatan kapal. Kondisi kesetimbangan kapal pada load case 1 disampaikan pada Tabel 5 .

Tabel 5. Kondisi kesetimbangan kapal pada load case 1

\begin{tabular}{lr}
\hline \multicolumn{3}{l}{ Hidrostatik Kapal Pada Kondisi Setimbang } \\
\hline Draft Amidsh. $m$ & 0.224 \\
Displacement tonne & 0.4787 \\
Heel to Starboard degrees & -1.5 \\
Draft at FP $\boldsymbol{m}$ & $\mathbf{0 . 1 6 1}$ \\
Draft at $\mathbf{A P} \boldsymbol{m}$ & $\mathbf{0 . 2 8 7}$ \\
Draft at LCF $m$ & 0.23 \\
Trim (+ve by stern) $m$ & 0.127 \\
\hline
\end{tabular}

\section{c. Kurva Stabilitas}

Kurva ini menyatakan lengan penegak (GZ) dan momen penegak (area dibawah kurva) untuk berbagai sudut oleng dari sudut $0^{\circ}$ sampai dengan $180^{\circ}$. Kurva stabilitas kapal klasik hasil desain untuk load case 1 digambarkan pada grafik Gambar 13. Berdasarkan kurva ini, dapat disimpulkan titik hilang stabilitas kapal ketika kapal oleng diantara sudut $120^{\circ}$ sampai dengan $130^{\circ}$.

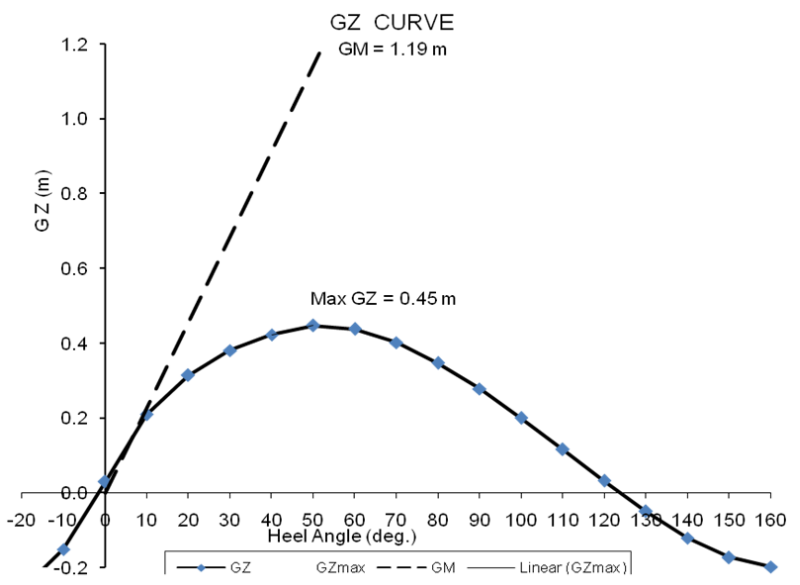

Gambar 13. Kurva stabilitas kapal klasik hasil desain untuk load case 1

\section{d. Kriteria Stabilitas}

Kriteria stabilitas mengacu pada ketentuan keselamatan kapal yang ditetapkan oleh International Maritime Organization (IMO) A.749(18) Ch3 [9] tentang kriteria desain untuk semua jenis kapal (Tabel 6)

Tabel 6. Kriteria stabilitas load case 1 menurut IMO

\begin{tabular}{|c|c|c|c|c|c|}
\hline Kode & Kriteria & Nilai & Unit & Aktual & Status \\
\hline \multirow{6}{*}{$\begin{array}{l}\text { A.749 } \\
(18) \\
\text { Ch3 - } \\
\text { Kriteria } \\
\text { desain } \\
\text { untuk } \\
\text { semua } \\
\text { kapal }\end{array}$} & $\begin{array}{l}\text { 3.1.2.1: } \\
\text { Area } 0 \text { to } \\
30\end{array}$ & 3,151 & m.deg & 7,415 & Pass \\
\hline & $\begin{array}{l}3.1 .2 .1: \\
\text { Area } 0 \text { to } \\
40\end{array}$ & 5,157 & m.deg & 11,445 & Pass \\
\hline & $\begin{array}{l}\text { 3.1.2.1: } \\
\text { Area } 30 \text { to } \\
40\end{array}$ & 1,719 & m.deg & 4,031 & Pass \\
\hline & $\begin{array}{l}\text { 3.1.2.2: } \\
\text { Max GZ } \\
\text { at } 30 \text { or } \\
\text { greater }\end{array}$ & 0,2 & $\mathrm{~m}$ & 0,449 & Pass \\
\hline & $\begin{array}{l}3.1 .2 .3: \\
\text { Angle of } \\
\text { maximum } \\
\text { GZ }\end{array}$ & 25 & deg & 52 & Pass \\
\hline & $\begin{array}{l}\text { 3.1.2.4: } \\
\text { Initial } \\
\text { GMt }\end{array}$ & 0,15 & $\mathrm{~m}$ & 1,189 & Pass \\
\hline
\end{tabular}

Berdasarkan perhitungan dengan aplikasi dibantu pemodelan dengan perangkat lunak 
komputer, maka semua kriteria terpenuhi (Pass). Dengan demikian untuk load case 1 stabilitas kapal telah sesuai dengan kriteria stabilitas yang telah ditetapkan IMO.

\subsection{Uji coba kapal}

Uji coba kapal dilaksanakan di Pantai Utara Pulau Jawa, yang merupakan bagian dari perairan Laut Jawa, tepatnya di perairan sekitar Pelabuhan Perikanan Nusantara (PPN) Brondong, Kabupaten Lamongan dengan perairan yang cukup tenang. Mesin yang digunakan adalah mesin sepeda motor $200 \mathrm{cc}$ dengan daya mesin $15 \mathrm{HP}$, dan kecepatan kapal yang diperoleh adalah sebesar 5,2 knot. Kecepatan maximum diperoleh ketika mesin diputar pada gigi kedua dengan separuh putaran mesin (RPM) maksimum dan kecepatan akan menurun ketika RPM mesin ditingkatkan. Hal ini masih memerlukan pengembangan untuk pemilihan propeller dan penyesuaian mesin untuk mendapatkan kecepatan maksimum. Penggunaan mesin kapal dengan menggunakan mesin diesel atau motor tempel sangat mungkin untuk mendapatkan daya dorong dan kecepatan kapal yang optimum.

\section{KESIMPULAN}

Desain kapal klasik dilihat secara estetika cukup indah dan menarik, penataan ruang diatas dek cukup baik dan nyaman sebagai sarana wisata. Namun demikian untuk digunakan sebagai kapal pancing dalam kegiatan wisata bahari maupun pemancingan komersial masih kurang menarik dikarenakan kapasitas orang yang dimuat hanya terbatas 5 orang. Rancang bangun kapal yang didesain dalam penelitian ini menunjukkan nilai kesetimbangan dan stabilitas yang baik Begitu pula saat dilakukan uji coba berlayar di perairan, kesetimbangan dan stabilitas kapal sangat baik, dan sesuai dengan International Maritime Organization (IMO) A.749(18) Ch3. Sebagai evaluasi dari hasil uji coba maka untuk penelitian lebih lanjut perlu dilakukan perbaikan pada sistem permesinan dan sistem propulsi untuk mendapatkan kecepatan kapal lebih optimum.

\section{UCAPAN TERIMA KASIH}

Penelitian ini merupakan bagian hasil dari penelitian dengan judul "Catamaran Motorboat Sebagai Sarana Transportasi Yang Efektif Untuk Kegiatan Perikanan dan Kelautan di Indonesia", yang merupakan penelitian hibah dengan pendanaan dari KEMENRISTEK DIKTI. Peneliti mengucapkan terima kasih kepada
KEMENRISTEK DIKTI, LPPM Universitas Brawijaya, serta Fakultas Perikanan dan Ilmu Kelautan, Universitas Brawijaya. Terimakasih juga disampaikan kepada keluarga Babur Royan yang telah menjadi mitra sebagai galangan kapal tradisional di Kecamatan Paciran, Kabupaten Lamongan.

\section{DAFTAR PUSTAKA}

[1] M. A, Rajab, A. Fahruddin dan I. Setyobudiandi, "Daya dukung perairan Pulau Liukang Loe untuk aktivitas ekowisata bahari”. DEPIK Jurnal Ilmu-Ilmu Perairan, Pesisir dan Perikanan, vol. 2(3), 2013.

[2] W. Amiruddin, I. Setiyanto dan E. S. Hadi, "Analisis Profitabilitas Peralihan Usaha Penangkapan Ikan Menjadi Usaha Persewaan Kapal wisata Bahari di Kepulauan Karimunjawa”. Kapal, vol. 7(1), pp.42-51, 2010.

[3] A. H. Pane, S. Samuel dan W. Amiruddin, "Analisa Teknis Dan Ekonomis Kapal KMP. Sapta Pesona Untuk Jalur Pelayaran Pantai Bandengan-Pulau Panjang Jepara Yang Mengalami Perubahan Fungsi". Jurnal Teknik Perkapalan, vol. 2(1), 2014.

[4] K. Khotimah dan H. Hasanudin, H., "Desain Kapal untuk Wisata Rute Bangsring-Pulau Menjangan-Pulau Tabuhan". Jurnal Teknik Institut Teknologi 10 Nopember, vol. 5(2), 2017.

[5] B. H. Susilo dan P. T. Esha, "Mengamati Keselamatan Penumpang Angkutan Sungai dan Danau". Jurnal Teknik Sipil, vol. 10(1), 2014.

[6] P. Manik, P, S. Jokosisworo dan B. A Laksana, "Pra Perancangan Kapal Pariwisata di Green Canyon Pangandaran”. Kapal, vol. 11(2), pp.77-84, 2014.

[7] A. Munazid, Studi Parametric Hullform Design dalam Kaitan dengan Kerakteristik Seakeeping dan Tahanan Kapal. Tugas Akhir, Pasca Sarjana Jurusan Teknik Sistem Perkapalan, Fakultas Teknologi KelautanInstitut Teknologi Sepuluh Nopember, Surabaya, 2010.

[8] E. Nelly, Simulasi Tahanan Gerak dan tenaga Efektif pada Kapal Payang, Kapal Pancing Mili-Mili dan Kapal Rawa Cucut. Penerbit IPB (Institut Pertanian Bogor), 1999.

[9] A. Gudmundsson, Safety practices related to small fishing vessel stability (No. 517). Food and Agriculture Organization of the United Nations (FAO), 2009. 